\title{
PAH metabolites in fish bile: from the Seine Estuary to Iceland
}

\author{
Kammann U. ${ }^{1}$, Akcha Farida ${ }^{2}$, Budzinski H. ${ }^{3}$, Burgeot Thierry ${ }^{2}$, Gubbins M.J. ${ }^{5}$, Lang T. ${ }^{1}$, \\ Le Menach K. ${ }^{3}$, Vethaak A.D. ${ }^{4}$, Hylland K. ${ }^{6,7}$
}

${ }^{1}$ Thünen Institut of Fishery Ecology, Palmaille 9, D-22767, Hamburg \& Deichstr. 12, 27472 Cuxhaven, Germany

${ }^{2}$ Department of Biogeochemistry and Ecotoxicology, Ifremer, BP 21105, 44311 Nantes Cedex 03,

France

${ }^{3}$ Université Bordeaux 1, Laboratory of Physico- and Toxico-Chemistry of the Environment (LPTC),

Molecular Sciences Institute (ISM), UMR 5255 CNRS, 33405 Talence, France

${ }^{4}$ P.O. Box 177, $2600 \mathrm{MH}$ Delft, The Netherlands \& Institute for Environmental Studies (IVM), VU

University Amsterdam, De Boelelaan 1087, 1081 HV Amsterdam, The Netherlands

${ }^{5}$ FRS Marine Laboratory, 375 Victoria Road, Aberdeen, AB11 9DB Scotland, UK

${ }^{6}$ Ketil Department of Biology, University of Oslo, Pb 1066, Blindern, N-0316 Oslo, Norway

${ }^{7}$ Norway \& Norwegian Institute for Water Research (NIVA), Gaustadalléen 21, N-0349 Oslo, Norway

* Corresponding author : U. Kammann, email address : ulrike.kammann@ti.bund.de

\begin{abstract}
:
Polycyclic aromatic hydrocarbons (PAH) are environmental contaminants that pose significant risk to health of fish. The International Workshop on Integrated Assessment of Contaminant Impacts on the North Sea (ICON) provided the framework to investigate biomarker responses as well as contaminant concentrations side by side in marine ecosystems. Concentrations of the main PAH metabolites 1hydroxypyrene, 1-hydroxyphenanthren and 3-hydroxybenzo(a)pyrene were determined in bile by HPLC with fluorescence detection. Fish species under investigation were dab (Limanda limanda), flounder (Platichthys flesus) and haddock (Melanogrammus aeglefinus). A contamination gradient was demonstrated from the low contaminated waters of Iceland and off-shore regions of the North Sea towards higher concentrations in coastal areas. Concentrations of PAH metabolites differed primarily according to sampling region and secondarily to species.
\end{abstract}

\section{Highlights}

PAH metabolites are useful for monitoring in marine fish species. A spatial gradient of increasing PAH contamination could be shown. Different fish species could join a pan-European assessment of $\mathrm{PAH}$ metabolites. Icelandic fish were used for the calculation of background assessment criteria. 
Keywords : PAH metabolite, Dab, Flounder, Haddock, Marine monitoring, Atlantic, North Sea

\section{Introduction}

Polycyclic aromatic hydrocarbons (PAHs) are ubiquitous contaminants in the marine environment (van der Oost et al., 2003). Because of some PAHs are known to be potent carcinogens, PAHs are generally regarded as a priority contaminants for environmental monitoring. Whereas PAH concentrations in water or sediment samples can be used to describe the contamination, the quantification of parent $\mathrm{PAHs}$ in fish tissues may lead to 
an underestimation of the exposure level. This is due to the fast metabolic transformation of PAHs in fish as well as in many other vertebrates. During this enzymatic biotransformation PAHs and arising intermediate compounds such as epoxides may act as genotoxic carcinogens leading to e.g. DNA adducts (Aas et al., 2000) and neoplasiarelated aberrations or tumors in fish liver (Myers et al., 2003; Vethaak et al., 2009). The resulting hydroxylated and/or conjugated $\mathrm{PAH}$ metabolites are mainly excreted via bile fluid. Therefore, the concentration of biliary $\mathrm{PAH}$ metabolites in fish can be used as a marker for assessing the recent $\mathrm{PAH}$ exposure. The main metabolite in fish bile is 1hydroxypyrene which contributes up to $76 \%$ of the sum of PAH metabolites. Other metabolites, detected in considerably lower levels in fish bile are 1-hydroxyphenanthrene, 1-hydroxychrysene and three metabolites of benzo(a)pyrene (Ruddock et al., 2003).

Biological effect monitoring including determination of $\mathrm{PAH}$ metabolites is part of international monitoring programmes, among them "OSPAR Joint Assessment and Monitoring Programme" (JAMP; OSPAR Commission, 2008) with dab and flounder as target species. PAH metabolites measured in fish bile are recommended for monitoring the PAH contamination of the North Sea. The analytical procedure is well documented and has been described in detail (e.g. Ariese et al., 2005a) and reviewed by Beyer et al. (2010). In addition an European quality assurance trial has been published (Kammann et al., 2013) and further quality assurance is performed under the lead of the ICES working group of biological effects of contaminants (WGBEC). With this comprehensive background PAH metabolites have become popular parameters in environmental monitoring in several European countries and are consequently part of recent international environmental assessments as well as recommendations (OSPAR Commission, 2008; HELCOM, 2013). The increasing international popularity of the method is based on a fast, easy and reproducible analytical procedure. It should be noted that HPLC analysis and the alternative gas chromatography-mass spectrometry (GC-MS) gave comparable results of PAH metabolites in fish bile (Ariese et al., 2005b; Kammann et al., 2013), so that effect thresholds determined by GC-MS are valid for HPLC too (ICES, 2011).

In addition the matrix bile is attractive as a liquid which is free of lipids and can be subjected after a simple enzymatic deconjugation step to the HPLC device. Further on bile can be easily collected from almost every fish with a filled gall bladder. Just after feeding the bile is emptied into the intestine and the gall bladder starts to refill again. PAH metabolite data are available for many different marine fish species such as flounder (Vuorinen et al., 2006, Kammann 2007), dab (van Schanke et al., 2001; Devier et al., 2013), cod (Karl et al., 2016; Ruus et al., 2012; Aas et al., 2000), turbot (Le Dû-Lacoste et al., 2013) and eel (Ruddock et al, 2003; Kammann et al., 2014). The concentration of PAH metabolites in fish bile includes information of bioavailability of $\mathrm{PAH}$ as well as the metabolic capacity of the animal. Therefore, PAH metabolites can be counted to both chemical and biological effects parameter. In contrast to many organic contaminants $\mathrm{PAH}$ do not accumulate in the fish and the concentration of PAH metabolites in the bile reflects exposure in the near past.

The ICON project (Hylland et al., 2012; 2015) is a demonstration program for integrated marine monitoring including biological effects in European marine waters. ICON provided the frame to investigate biomarker responses as well as contaminant concentrations side by side in marine samples (Broeg et al., 2016). Several laboratories in charge for national monitoring joined this project to exchange knowledge and contribute to a joint assessment on European scale. This approach is in line with the goals of the EU Marine Strategy Framework Directive (MSFD, 2008). The MSFD requires that "Concentrations of 
contaminants are at levels not giving rise to pollution effects" in order for Good Environmental Status to be achieved. Monitoring and assessment strategies concerning MSFD are currently under international discussion. ICES and OSPAR provide a detailed framework and example for environmental assessment as demanded by MSFD (Davies and Vethaak, 2012). A central part of the recommended strategy is a categorization of results by assessment criteria acting as (1) thresholds between background and elevated but acceptable levels (background assessment concentration, BAC), and (2) between acceptable and unacceptable levels (environmental assessment concentration, EAC).

The aims of the present study are related to the integrated assessment addressed in ICON: (1) To compare levels of PAH metabolites in fish from NW European marine and estuarine waters; to (2) compare levels of PAH metabolites in different fish species and (3) to provide background concentrations needed for environmental assessment.

\section{Material and Methods}

\section{Fish collection and bile sampling}

Fish were sampled during cruises of RV "Walther Herwig III" in 2008 by means of bottom trawling in the North Sea and western Baltic. The sampling stations are shown in Fig. 1. For this study adult female dab (Limanda limanda) with a body length between 20 and 26 $\mathrm{cm}$ as well as adult male or female flounder (Platichthys flesus) with a body length between 24 and $31 \mathrm{~cm}$ were used. Haddock (Melanogrammus aeglefinus) of both sexes with body length between 28 and $45 \mathrm{~cm}$ were also included in the study. In the Dutch Wadden Sea adult male or female flounder with a body length between 24 and $30 \mathrm{~cm}$ were caught in September 2008 using a small beam trawl. Dab and flounder from the Seine estuary were sampled during cruises of the French ship "Gwendrez" in September 2008 by means of bottom trawling. The body length was determined with 20 to $26.5 \mathrm{~cm}$ for dab and 24.5 to $31.5 \mathrm{~cm}$ for flounder (Table 1). All sampling campaigns took place in August or September and were in accordance with the OSPAR sampling strategy (OSPAR Commission, 2008). Fish were killed by a blow on the head and bile fluid was sampled using a $1 \mathrm{ml}$ disposable syringe with a disposable hypodermic needle $(0.6 \times 30 \mathrm{~mm})$. Bile samples of approximately $0.1-0.5 \mathrm{ml}$ were immediately frozen and stored at $-20^{\circ} \mathrm{C}$ or lower until analysis.

\section{$\underline{\text { Chemicals }}$}

The hydroxylated PAH standards 1-hydroxypyrene (1OHPyr) and 1-hydroxyphenanthrene (1OHPhen) were supplied by Dr. Ehrenstorfer GmbH (Augsburg, Germany) as certified solutions. Acetonitrile (hypergrade for HPLC), methanol (gradient grade, for HPLC), ethanol (absolute), trifluoroacetic acid (spectroscopic quality) and Bglucuronidase/arylsulfatase $(30 / 60 \mathrm{U} / \mathrm{ml})$ were purchased by VWR International $\mathrm{GmbH}$ (Darmstadt, Germany). Ascorbic acid and 3-hydroxybenzoapyren (3OHBAP) as neat certified reference material (BCR 343) were purchased by Sigma-Aldrich (Taufkirchen, Germany) and water in HPLC gradient grade quality was purchased by J.T. Baker (Netherlands).

\section{Treatment of bile samples}

PAH metabolites in bile samples were determined as described by Kammann et al (2014). Briefly, $25 \mu \mathrm{l}$ bile was mixed with $95 \mu \mathrm{l}$ water and $5 \mu \mathrm{l}$ of an enzyme solution containing Bglucuronidase/arylsulfatase $(30 / 60 \mathrm{U} / \mathrm{ml})$. The resultant mixture was shaken for $2 \mathrm{~h}$ at 37 ${ }^{\circ} \mathrm{C}$. The reaction was stopped by addition of $125 \mu$ l ethanol containing $5 \mathrm{mg} / \mathrm{ml}$ ascorbic 
acid. The final solution was centrifuged $(5 \mathrm{~min}, 700 \times \mathrm{g})$. The clear supernatant was transferred to $\mathrm{HPLC}$ vials, stored at $10^{\circ} \mathrm{C}$ in the auto sampler and used for HPLC analysis at the same day.

\section{HPLC analysis for PAH metabolites}

The concentrations of the three metabolites were determined using a LaChrom HPLC system (Merck Hitachi) comprising a quaternary pump (L-7100), an auto sampler (L-7200) and a fluorescence detector (L-7480). Samples were chromatographed on a Nucleosil $100-3 \mathrm{C} 18(3 \times 125 \mathrm{~mm})$ reverse phase column equipped with a $10 \times 3 \mathrm{~mm}$ guard column filled with the same material. Standard solutions were diluted in acetonitrile containing 5 $\mathrm{mg} / \mathrm{ml}$ ascorbic acid and stored in the dark. Calibrations consisting of five standard concentrations were repeated daily with every sample batch. The initial mobile phase was acetonitrile $/ 0.1 \%$ trifluoroacetic acid 50/50 (v/v) pumped with $0.5 \mathrm{ml} / \mathrm{min}$. After $10 \mathrm{~min}$ the solvent composition progressively changed to $60 / 40$ within 4 min and afterwards to $100 \%$ acetonitrile over $2 \mathrm{~min}$. The gradient remained on this level for additional $3 \mathrm{~min}$ and returned to the initial composition within $1 \mathrm{~min}$. The excitation/emission wavelength pairs for $1 \mathrm{OHPyr}$ and $1 \mathrm{OHPhen}$ were $346 / 384$ and $256 / 380 \mathrm{~nm}$ respectively. The wavelength pair used for 30 HBAP was $380 / 430 \mathrm{~nm}$.

\section{Quality assurance and statistics}

The limit of detection (LD) and the limit of quantification (LQ) were calculated from a standard curve according to DIN 32645 (DIN, 1994) with a confidence level of $99 \%$. Considering the dilution of the sample during sample preparation a LD of 0.68 and a LQ of $4.50 \mathrm{ng} / \mathrm{ml}$ bile were determined for 1OHPyr. For 1OHPhen (3OHBAP) a LD of $0.10(4.06)$ and a LQ of $0.33(12.92) \mathrm{ng} / \mathrm{ml}$ were calculated respectively. All results, including those below LD or LQ, were used for mean calculation. No substitution by LD or 0.5 LD was performed. A fish bile sample as laboratory reference material was included in every sample batch to monitor the stability of the method (variation coefficient $15 \%$ for $1 \mathrm{OHPyr}$ ). External quality assurance was performed by an intercalibration exercise of the method leading to a mean z-score of -0.5 for 1 OHPyr (Kammann et al., 2013).

Significant differences in 1OHPyr concentration between species were tested with the post-hoc test: Fisher least significant difference with a p-value of 0.05 using STATISTICA 6.0 (Stat Soft, USA)

\section{Calculation of BAC}

BACs were calculated separately for each species and specific for different PAH metabolites. The strategy used is in accordance with ICES (2011) and Davies and Vethaak (2012): BAC is defined as the $90^{\text {th }}$ percentile of concentrations measured in a reference area assuming that the level in this area is close to background concentration. The upper 10 percent are excluded to eliminate possible outliers.

\section{Results}

Three PAH metabolites 1OHPyr, 1OHPhen and 3OHBAP were determined in 231 individual bile samples. The concentrations in individual fish ranged from $<\mathrm{LD}$ to $654 \mathrm{ng} / \mathrm{ml}$ for 1OHPyr (Table 1, Table 2), the dominating metabolite in all fish species. The highest mean concentration per species and location of $10 \mathrm{HPyr}, 373 \mathrm{ng} / \mathrm{ml}$, was analysed in flounder from the river Alde in UK, where also the highest mean level per species and location for 1 OHPhen, $22 \mathrm{ng} / \mathrm{ml}$, was found. However, seven individual fish $(=3 \%)$ from the North Sea locations P01, N01 and from the western Baltic (B12) exhibited 1OHPhen 
concentrations of $24 \mathrm{ng} / \mathrm{ml}$ or higher. The concentrations of 3 OHBAP were generally low and came below LQ or even LD in most samples. Highest levels of 30 HBAP were detected in fish from the western Baltic with a mean per species and location of $22 \mathrm{ng} / \mathrm{ml}$ for flounder and a maximum individual concentration of $60 \mathrm{ng} / \mathrm{ml}$. Fish from the German Bight as well as from the Seine estuary exceeded the LQ for 3OHBAP showing a higher level of contamination of the carcinogenic benzo(a)pyrene in these areas compared to the off-shore regions of the North Sea or Iceland.

In general fish from the rivers and estuaries exhibited the highest PAH contamination followed by fish from coastal areas and off-shore marine regions (Fig. 1). Lowest concentrations of PAH metabolites were found in fish caught close to Iceland. Low contaminated areas might be regarded as contaminated close to background values. The sampling positions were grouped in 7 regions (Table 1) exhibiting increasing mean concentrations of 1OHPyr in the order Iceland $\approx$ North Sea off-shore < Dutch coast < German Bight $<$ western Baltic < Seine Estuary France $\approx$ Alde river UK. The order of increasing mean concentrations for 3 OHBAP was different: Dutch coast $\approx$ Iceland $\approx$ Alde river UK $\approx$ North Sea off-shore $<$ German Bight $<$ Seine Estuary France $<$ western Baltic.

[Figure 1]

[Table 1]

\section{Discussion}

For environmental assessments on European scale it might be advantageous to include results from different fish species and habitats in one evaluation. In this case problems arising from biological differences have to be balanced with the benefit of the bigger geographical coverage. Most studies are focussed on one species only to rule out the possible biologic bias. Our results indicate that for PAH metabolites an assessment across different species might be appropriate in the future: It is evident from Table 1 that differences in 1OHPyr concentrations between the species are low compared to regional differences in the present study. However, with the limited set of data this hypothesis needs to be confirmed. Further we showed that the two flatfish species dab and flounder, which live in close association with PAH-containing sediment, are not higher contaminated than the pelagic haddock. No significant difference between dab and haddock in Iceland or in the North Sea off-shore region could be found. This leads to the possibility that the difference of pelagic or benthic life style might not be crucial for PAH metabolite concentrations in the bile. However, it should be taken into account that this assumption is based on a single sampling occasion, might not hold for regions with higher contamination and therefore needs further work. We tentatively conclude that assuming bigger regional differences in PAH contaminations, more than one fish species might be included in a regional assessment. However, this factor is increasing the variance of the dataset and should be carefully considered.

PAH metabolites reflect the level of general PAH contamination and show a clear gradient from pristine locations (Iceland and North Sea off-shore) over coastal marine areas (Dutch coast, German Bight, western Baltic) to European rivers and estuaries in UK and France. In the present study the contamination of 1OHPyr ranges over two decades from $3 \mathrm{ng} / \mathrm{ml}$ in Icelandic haddock to over $300 \mathrm{ng} / \mathrm{ml}$ in dab and flounder from France and UK. The overall contamination levels in the regions are in good accordance with previous studies on dab (Devier et al., 2013), cod (Karl et al., 2016) and flounder (Vuorinen et al., 2006, 
Ruczyńska et al., 2011). In comparison, fresh water fish like the European eel can exhibit $10 H$ Pyr concentrations above $3000 \mathrm{ng} / \mathrm{ml}$ (Kammann et al., 2014).

252 Highest 3OHBAP concentrations in the Baltic (Table 1) underline the general high 253 contamination of this area (Karl et al., 2016) as well as with carcinogenic benzo(a)pyrene, 254 which might be harmful for the organisms in this ecosystem. The concentrations of 3OHBAP determined in the present study are in line with Ruczyńska et al., 2011 and Ruddock et al., 2002. In European guidelines only the PAH metabolites 1OHPyr and 10HPhen are mentioned for environmental monitoring. Other metabolites are present in marine fish bile samples as well but are usually so low concentrated that they are touching the LQ or LD. It is challenging to include censored data in a big assessment and data on 3 OHBAP are scarce. However, in the present study we could show that, 3OHBAP is not always distributed like the main metabolite 1OHPYR. In fact both metabolites may exhibit different spatial patterns. The direct relation of 3 OHBAP levels in bile and genotoxic effects in fish blood has been shown by Brinkmann et al. (2010). Our results indicate that toxicological relevant $\mathrm{PAH}$ metabolites like 3 OHBAP should be included in future monitoring programmes, especially in the Baltic Sea, and cannot be substituted by 10 HPyr. Future quality assurance trials as well as threshold levels or 3 OHBAP have to be established to reach this goal.

To assess the possible harm of $\mathrm{PAH}$ contamination for the organisms the measured concentrations of $\mathrm{PAH}$ metabolites were compared to internationally agreed EAC as published by ICES (Davies and Vethaak, 2012). In the present study only 7 single fish exceed the EAC for $10 \mathrm{HPyr}, 483 \mathrm{ng} / \mathrm{ml}$ calculated for cod, but no fish exceeds the EAC of 745 or $909 \mathrm{ng} / \mathrm{ml}$ calculated for turbot and halibut respectively (Davies and Vethaak, 2012). Even if those thresholds have been calculated for other marine fish species, this comparison indicates that the $\mathrm{PAH}$ contamination in the fish under investigation does not rise big concern in general. The respective EAC for $10 H P h e n$ is not exceeded in any case. To the authors knowledge no such thresholds for "unacceptable effects" exist for dab, flounder or haddock. However, it cannot be excluded that PAH together with other contaminants or environmental threats may produce synergistic effects which may lead to harm for the organism. It should also be noted that some flounder from UK and France exceed the EAC calculated for cod pointing on a possible contamination problem in these regions. Furthermore EAC for $30 \mathrm{HBAP}$ are completely missing.

As described above the pristine area of Iceland was identified as low contaminated. We propose this region as reference area to calculate BAC for dab and haddock. This is also supported by findings of Hylland et al. (2016) in the same region. The BAC presented in Table 2. are in good accordance with levels published before (Lyons et al., 2010, Davies and Vethaak, 2012). Due to concentrations of 3OHBAP below LD in many samples from Iceland no BAC could be calculated for this metabolite.

[Table 2]

\section{Conclusions}

This study points out the usefulness of PAH metabolites as monitoring tool in marine fish species which was recently underlined by recommendation of $\mathrm{PAH}$ metabolites as core indicator by HELCOM (2013).

It could be shown that a gradient of increasing contamination exist from pristine areas like Iceland and the off-shore regions in the North Sea towards coastal and estuarine areas in Europe. This study also provides indications to possibly combine marine fish species to a joint pan-European assessment of PAH metabolites. The levels of $1 \mathrm{OHPyr}$ in Icelandic fish 
are generally low and can be regarded as background and have consequently being used for the calculation of BAC. 3OHBAP should be considered as additional PAH metabolite in future monitoring as soon as assessment criteria for this parameter are available.

\section{Acknowledgments}

The authors wish to thank Alexander Schulz for his skillful assistance in HPLC analysis and the French contribution of the "Gwendrez" from Ifremer in the Seine estuary.

\section{References}

Aas, E., Baussant, T., Balk, L., Liewenborg, B., Andersen, O.K., 2000. PAH metabolites in bile, cytochrome P4501A and DNA adducts as environmental risk parameters for chronic oil exposure: a laboratory experiment with Atlantic cod. Aquat Toxicol 51, 241258

Ariese, F., Beyer, J., Jonsson, G., Porte Visa, C., Krahn, M.M., 2005a. Review of analytical methods for determining metabolites of polycyclic aromatic compounds (PACs) in fish bile. ICES Techniques in Marine Environmental Sciences No. 39, 41pp. International Council for the Exploration of the Sea, ICES, Copenhagen, Denmark

Ariese, F., Beyer, J., Wells, D., 2005b. Two fish bile reference materials certified for PAH metabolites. J Environ Monitor 7, 869-876

Beyer, J., Jonsson, G., Porte, C., Krahn, M.M., Ariese, F. 2010. Analytical methods for determining metabolites of polycyclic aromatic hydrocarbon (PAH) pollutants in fish bile: A review. Environ Toxicol Phar 30, 224-244

Brinkmann, M., Hudjetz, S., Cofalla, C., Roger, S., Kammann, U., Zhang, X., Wiseman, S., Giesy, J., Hecker, M., Schüttrumpf, H., Wölz, J., Hollert, H., 2010. A combined hydraulic and toxicological approach to assess re-suspended sediments during simulated flood events. Part I - multiple biomarkers in rainbow trout. J Soil Sediment 10, 1347-1361

Broeg, K., Kammann, U., Hoeher, N., Lang, T., 2016. Lysosomal membrane stability in the liver of dab (Limanda limanda) - Applicability and reliability of assessment criteria under concrete contaminant-related monitoring conditions of coastal, estuarine and offshore locations. Mar Environ Res in press

Davies, I.M., Vethaak, A.D., 2012. Integrated marine environmental monitoring and their effects. ICES Cooperative Research report No. 315. 270 pp.

Devier, M.-H., Le Du-Lacoste, M., Akcha, F. et al., 2013. Biliary PAH metabolites, EROD activity and DNA damage in dab (Limanda limanda) from Seine Estuary (France). Environ Sci Pollut Res 20, 708-722

DIN, 1994. Deutsches Institut für Normung e.V. (DIN) 32645, Nachweis-, Erfassungs- und Bestimmungsgrenze. Berlin Beuth Verlag, Berlin

HELCOM, 2013. HELCOM core indicators -Final report of the HELCOM CORESET project, Baltic Sea Environment Proceedings No. 136, $71 \mathrm{pp}$. http://www.helcom.fi/Documents/Ministerial2013/Associated\%20documents/Backgroun d/CORESET Final BSEP136.pdf\#search=helcom\%20coreset\%20contaminants (accessed 13.4.2015)

Hylland, K., Burgeot, T., Martínez-Gómez, C., Lang, T., Robinson, C.D., Svavarsson, J., Thain, J.E., Vethaak, A.D., Gubbins, M.J., 2015. How can we quantify impacts of contaminants in marine ecosystems? The ICON project. Mar Environ Res. doi: 10.1016/j.marenvres.2015.11.006.

Hylland, K., Gubbins, M., Robinson, C., Lang, T., Vethaak, A.D., Martinez-Gomez, C., Burgeot, T., Svavarsson, J., Thain, J.E., 2012. Theory and practice of integrated 
monitoring in marine ecosystems - The ICON programme. Comparative Biochemistry and Physiology A 163, 51-52

Hylland, K., Skei, B.B., Brunborg, G., Lang, T., Gubbins, M.J., le Goff, J., Burgeot, T., 2016. DNA damage in dab (Limanda limanda) and haddock (Melanogrammus aeglefinus) from European seas Mar Environ Res, in press http://dx.doi.org/10.1016/j.marenvres.2016.01.001. (accessed 24.2.2016)

ICES, 2011. Report of the Joint ICES/OSPAR Study Group on Integrated Monitoring of Contaminants and Biological Effects (SGIMC) ICES CM 2011 /ACOM:30 REF. ACOM, OSPAR http://www.ices.dk/sites/pub/Publication\%20Reports/Expert\%20Group\%20Report/aco $\mathrm{m} / 2011 /$ SGIMC/sgimc 2011 final.pdf (accessed 13.4.2015)

Kammann, U., 2007. PAH metabolites in bile fluids of dab (Limanda limanda) and flounder (Platichthys flesus) - spatial distribution and seasonal changes. Environ Sci Pollut Res 14, 102-108

Kammann, U., Askem, C., Dabrowska, H., Grung, M., Kirby, M.F., Koivisto, P., Lucas, C., McKenzie, M., Meier, S., Robinson, C., Tairova, Z.M., Tuvikene, A., Vuorinen, P.J., Strand, J., 2013. Interlaboratory proficiency testing for measurement of the PAH metabolite 1-hydroxypyrene in fish bile for marine environmental monitoring, J AOAC Int 96, 635-641

Kammann, U., Brinkmann, M., Freese, M., Pohlmann, J.-D., Stoffels, S., Hollert, H., Hanel, R., 2014. PAH metabolites, GST and EROD in European eel (Anguilla anguilla) as possible indicators for eel habitat quality in German rivers, Environ Sci Pollut Res 21, 2519-2530

Karl, H., Kammann, U., Aust, M.-O., Manthey-Karl, M., Lüth, A., Kanisch, G., 2016. Large scale distribution of dioxins, PCBs, heavy metals, PAHmetabolites and radionuclides in cod (Gadus morhua) from the North Atlantic and its adjacent seas. Chemosphere 149, 294-303

Le Dû-Lacoste, M., Akcha, F., Devier, M.-H., Morin, B., Burgeot, T., Budzinski, H., 2013. Comparative study of different exposure routes on the biotransformation and genotoxicity of PAHs in the flatfish species, Scophthalmus maximus. Environ Sci Pollut Res 20, 690-707

Lyons, B.P., Thain, J.E., Hylland, K., Davis, I., Vethaak, A.D., 2010. Using biological effects tools to define Good Environmental Status under the Marine Strategy Framework Directive. Marine Pollution Bulletin 60, 1647-1651

MSFD (2008) European Union Marine Strategy Framework Directive [http://ec.europa.eu/environment/water/marine]

Myers, M.S., Johnson, L.L., Collier, T.K., 2003. Establishing the causal relationship between polycyclic aromatic hydrocarbon (PAH) exposure and hepatic neoplasms and neoplasia-related liver lesions in English sole (Pleuronectes vetulus). Hum Ecol Risk Assess 9, 67-94

OSPAR Commission, 2008. Co-ordinated Environmental Monitoring Programme (CEMP) http://www.ospar.org/content/content.asp?menu=00900301400000 13.4.2015)

Ruczyńska, W.M., Szlinder-Richert, J., Malesa-Ciećwierz, M., Warzocha, J., 2011. Assessment of $\mathrm{PAH}$ pollution in the southern Baltic Sea through the analysis of sediment, mussels and fish bile. J Environ Monit 13, 2535-2542

Ruddock, P.J., Bird, D.J., McCalley, D.V., 2002. Bile metabolites of polycyclic aromatic hydrocarbons in three species of fish from the severn estuary. Ecotoxicol Environ Saf 51, 97-105 
Ruddock, P.J., Bird, D.J., McEvoy, J., Peters, L.D., 2003. Bile metabolites of polycyclic aromatic hydrocarbons (PAHs) in European eels Anguilla anguilla from United Kingdom estuaries. Sci Total Environ 301, 105-117

Ruus, A., Daae, I.A., Hylland, K., 2012. Accumulation of polychlorinated biphenyls from contaminated sediment by Atlantic cod (Gadus morhua): Direct accumulation from resuspended sediment and dietary accumulation via the polychaete Nereis virens Environ Toxicol Chem 31, 2472-2481

Van der Oost, R., Beyer, J., Vermeulen, N.P.E., 2003. Fish bioaccumulation and biomarkers in environmental risk assessment: a review. Environ Toxicol Pharmacol 13, 57-149

Van Schanke, A., Holtz, F., van der Meer, J., Boon, J.P., Ariese, F., Stroomberg, G., van den Berg, M., Everaarts, J.M., 2001. Dose- and time dependent formation of biliary benzo[a]pyrene metabolites in the marine flatfish dab (Limanda limanda). Environ Toxicol Chem 20, 1641-1647

Vethaak, A.D., Jol, J.G., Pieters, J.P., 2009. Long-term trends in the prevalence of cancer and other major diseases among flatfish in the southeastern North Sea as indicators of changing ecosystem health. Environmental Science \& Technology 43, 2151-2158

Vuorinen, P.J., Keinänen, M., Vuontisjärvi, H., Barsiene, J., Broeg, K., Förlin, L., Gercken, J., Kopecka, J., Köhler, A., Parkkonen, J., Pempkowiak, J., Schiedek, D., 2006. Use of biliary PAH metabolites as a biomarker of pollution in fish from the Baltic Sea. Mar Pollut Bull 53, 479-487

\section{Figure Captions}

Fig. 1 Mean values of the PAH metabolite 1-hydroxypyrene (1OHPyr) in dab: Iceland, France, North Sea, German Bight and western Baltic. 
Table 1.: Origin of samples, species, number (n), fish length and concentrations of PAH metabolites 1-hydroxypyrene (1OHPyr), 1-hydroxyphenanthrene (1OHPhen) and 3-hydroxybenzo(a)pyrene (3OHBAP) given as mean, minimum and maximum per station in ng/ml. Values below limit of detection or limit of quantification were substituted by " $<$ " and the respective thresholds after mean calculation . n.d.: not determined.

\begin{tabular}{|c|c|c|c|c|c|c|c|c|c|c|c|c|c|c|c|c|}
\hline \multirow[t]{2}{*}{ Area } & \multirow{2}{*}{\begin{tabular}{|l|}
\multicolumn{1}{|c}{ Station } \\
code
\end{tabular}} & \multirow[t]{2}{*}{ Position } & \multirow[t]{2}{*}{ Species } & \multirow[t]{2}{*}{$n$} & \multicolumn{3}{|c|}{ Length $[\mathrm{cm}]$} & \multicolumn{3}{|c|}{ 1OHPyr [ng/ml] } & \multicolumn{3}{|c|}{ 1-OH-Phen [ng/ml] } & \multicolumn{3}{|c|}{ 3-OH-BAP [ng/ml] } \\
\hline & & & & & mean & $\min$ & $\max$ & mean & $\min$ & $\max$ & mean & $\min$ & $\max$ & mean & $\min$ & $\max$ \\
\hline \multirow{5}{*}{ Iceland } & \multirow{2}{*}{116} & \multirow{2}{*}{$\begin{array}{l}63^{\circ} 40.00^{\prime} \mathrm{N} \\
16^{\circ} 10.00^{\prime} \mathrm{W} \\
\end{array}$} & dab & 11 & 24.2 & 21 & 26 & 7.64 & $<4.50$ & 13.72 & 1.88 & $<0.10$ & 3.45 & $<4.06$ & $<4.06$ & $<4.06$ \\
\hline & & & haddock & 22 & 39.3 & 33 & 45 & $<4.50$ & $<0.68$ & 18.58 & $<0.33$ & $<0.10$ & 1.58 & $<4.06$ & $<4.06$ & $<4.06$ \\
\hline & \multirow{3}{*}{120} & \multirow{3}{*}{$\begin{array}{l}64^{\circ} 00.00^{\prime} \mathrm{N} \\
22^{\circ} 15.00^{\prime} \mathrm{W}\end{array}$} & dab & 15 & 23.9 & 21 & 26 & 9.69 & $<4.50$ & 24.41 & 0.65 & $<0.10$ & 3.66 & $<4.06$ & $<4.06$ & 19.90 \\
\hline & & & \begin{tabular}{|l|} 
flounder \\
\end{tabular} & 2 & 30.7 & 30 & 31 & 18.36 & 15.21 & 21.51 & 0.38 & $<0.10$ & 0.68 & $<4.06$ & $<4.06$ & $<4.06$ \\
\hline & & & haddock & 22 & 36.9 & 32 & 44 & 6.63 & $<4.50$ & 20.32 & $<0.33$ & $<0.10$ & 1.99 & $<4.06$ & $<4.06$ & $<4.06$ \\
\hline \multirow{7}{*}{$\begin{array}{l}\text { North Sea. } \\
\text { off-shore }\end{array}$} & GB3 & $\begin{array}{l}54^{\circ} 55.00^{\prime} \mathrm{N} \\
06^{\circ} 15.00^{\prime} \mathrm{E}\end{array}$ & dab & 9 & 23.3 & 21 & 24 & 43.55 & 20.75 & 92.58 & 1.45 & $<0.10$ & 2.86 & $<4.06$ & $<4.06$ & $<12.92$ \\
\hline & N04 & $\begin{array}{l}54^{\circ} 25.00^{\prime} \mathrm{N} \\
02^{\circ} 00.00^{\prime} \mathrm{E}\end{array}$ & dab & 9 & 22.4 & 21 & 24 & 8.16 & 4.77 & 11.86 & 1.22 & $<0.10$ & 3.27 & $<4.06$ & $<4.06$ & $<4.06$ \\
\hline & \multirow{2}{*}{ N06 } & \multirow{2}{*}{$\begin{array}{l}56^{\circ} 15.00^{\prime} \mathrm{N} \\
01^{\circ} 44.00^{\prime} \mathrm{W}\end{array}$} & dab & 8 & 22.1 & 21 & 23 & 11.56 & 4.74 & 30.27 & 1.08 & $<0.10$ & 4.63 & $<4.06$ & $<4.06$ & $<12.92$ \\
\hline & & & haddock & 5 & 32.8 & 28 & 37 & 6.43 & $<4.50$ & 9.16 & $<0.33$ & $<0.10$ & 0.65 & $<4.06$ & $<4.06$ & $<4.06$ \\
\hline & N11 & $\begin{array}{l}55^{\circ} 30.00^{\prime} \mathrm{N} \\
06^{\circ} 49.00^{\prime} \mathrm{E} \\
\end{array}$ & dab & 6 & 22.8 & 20 & 24 & 39.53 & 15.65 & 66.26 & 3.45 & 1.77 & 5.48 & $<12.92$ & $<4.06$ & $<12.92$ \\
\hline & P01 & $\begin{array}{l}55^{\circ} 22.00^{\prime} \mathrm{N} \\
04^{\circ} 40.00^{\prime} \mathrm{E}\end{array}$ & dab & 12 & 22.9 & 21 & 24 & 26.39 & 10.81 & 59.92 & 6.11 & $<0.10$ & 39.87 & $<4.06$ & $<4.06$ & $<4.06$ \\
\hline & P02 & \begin{tabular}{|l|}
$56^{\circ} 16.00^{\prime} \mathrm{N}$ \\
$02^{\circ} 40.00^{\prime} \mathrm{E}$ \\
\end{tabular} & dab & 11 & 22.5 & 20 & 25 & 13.93 & $<4.50$ & 25.82 & $<0.10$ & $<0.10$ & $<0.33$ & $<4.06$ & $<4.06$ & $<4.06$ \\
\hline $\begin{array}{l}\text { North Sea } \\
\text { Dutch coast }\end{array}$ & - & $\begin{array}{l}53^{\circ} 30.00^{\prime} \mathrm{N} \\
06^{\circ} 00.00^{\prime} \mathrm{E} \\
\end{array}$ & flounder & 13 & n.d. & n.d. & n.d. & 76.99 & 44.48 & 148.36 & 1.96 & 0.55 & 4.15 & $<4.06$ & $<4.06$ & $<4.06$ \\
\hline \multirow{2}{*}{$\begin{array}{l}\text { North Sea } \\
\text { German Bight }\end{array}$} & GB1 & $\begin{array}{l}54^{\circ} 04.00^{\prime} \mathrm{N} \\
07^{\circ} 43.00^{\prime} \mathrm{E} \\
\end{array}$ & dab & 2 & 22.0 & 22 & 22 & 88.48 & 42.78 & 134.18 & 2.38 & 2.04 & 2.72 & $<12.92$ & $<4.06$ & $<12.92$ \\
\hline & N01 & $\begin{array}{l}54^{\circ} 15.00^{\prime} \mathrm{N} \\
07^{\circ} 25.00^{\prime} \mathrm{E}\end{array}$ & dab & 8 & 23.1 & 21 & 25 & 83.21 & 12.75 & 430.33 & 5.83 & 0.59 & 24.32 & $<12.92$ & $<4.06$ & 25.58 \\
\hline \multirow{2}{*}{ Western Baltic } & \multirow{2}{*}{ B12 } & \multirow{2}{*}{$\begin{array}{l}54^{\circ} 12.00^{\prime} \mathrm{N} \\
11^{\circ} 22.00^{\prime} \mathrm{E}\end{array}$} & dab & 14 & 23.9 & 23 & 25 & 115.06 & 81.61 & 175.56 & 4.32 & 2.71 & 7.45 & 15.03 & $<12.92$ & 25.41 \\
\hline & & & flounder & 24 & 28.4 & 25 & 31 & 209.21 & 77.08 & 653.72 & 7.93 & 2.71 & 33.77 & 22.44 & $<12.92$ & 60.32 \\
\hline \multirow{2}{*}{$\begin{array}{l}\text { France } \\
\text { Seine Estuary }\end{array}$} & \multirow{2}{*}{ F03 } & \multirow{2}{*}{$\begin{array}{l}51^{\circ} 30.00^{\prime} \mathrm{N} \\
00^{\circ} 30.00^{\prime} \mathrm{E}\end{array}$} & dab & 4 & 24 & 20 & 26 & 345.38 & 272.57 & 416.59 & 2.31 & 0.91 & 3.36 & $<12.92$ & $<12.92$ & $<12.92$ \\
\hline & & & flounder & 18 & 27 & 25 & 32 & 316.49 & \begin{tabular}{|l|}
158.43 \\
\end{tabular} & 587.03 & 7.49 & 1.95 & 13.10 & $<12.92$ & $<12.92$ & 22.94 \\
\hline $\begin{array}{l}\text { UK } \\
\text { Alde river }\end{array}$ & - & & flounder & 16 & 27.7 & 24 & 31 & 373.24 & 207.65 & 653.87 & 22.46 & 8.21 & 56.02 & $<4.06$ & $<4.06$ & $<12.92$ \\
\hline All & & & & 231 & 27.9 & 20 & 45 & 100.87 & $<0.68$ & 653.87 & 4.33 & $<0.10$ & 56.02 & $<12.92$ & $<4.06$ & 60.32 \\
\hline
\end{tabular}


Table 2.: PAH metabolites 1-hydroxypyrene (1OHPyr) and 1-hydroxyphenanthrene (1OHPhen) in fish caught in Iceland area. Mean, standard deviation $(\mathrm{SD})$ and $\mathrm{BAC}=$ background assessment concentration $=90^{\text {th }}$ percentile. $\mathrm{N}$ : number of fish.

\begin{tabular}{|l|r|r|r|r|r|r|r|}
\hline species & N & \multicolumn{4}{|l|}{ 1OHPyr $[\mathrm{ng} / \mathrm{ml}]$} & \multicolumn{4}{l|}{ 1OHPhen [ng/ml] } \\
\hline & & Mean & SD & BAC & Mean & SD & BAC \\
\hline dab & 26 & 8.82 & 4.83 & 13.72 & 1.17 & 1.26 & 3.42 \\
\hline haddock & 44 & 4.81 & 4.66 & 10.13 & $<0.33$ & 0.51 & 0.64 \\
\hline
\end{tabular}




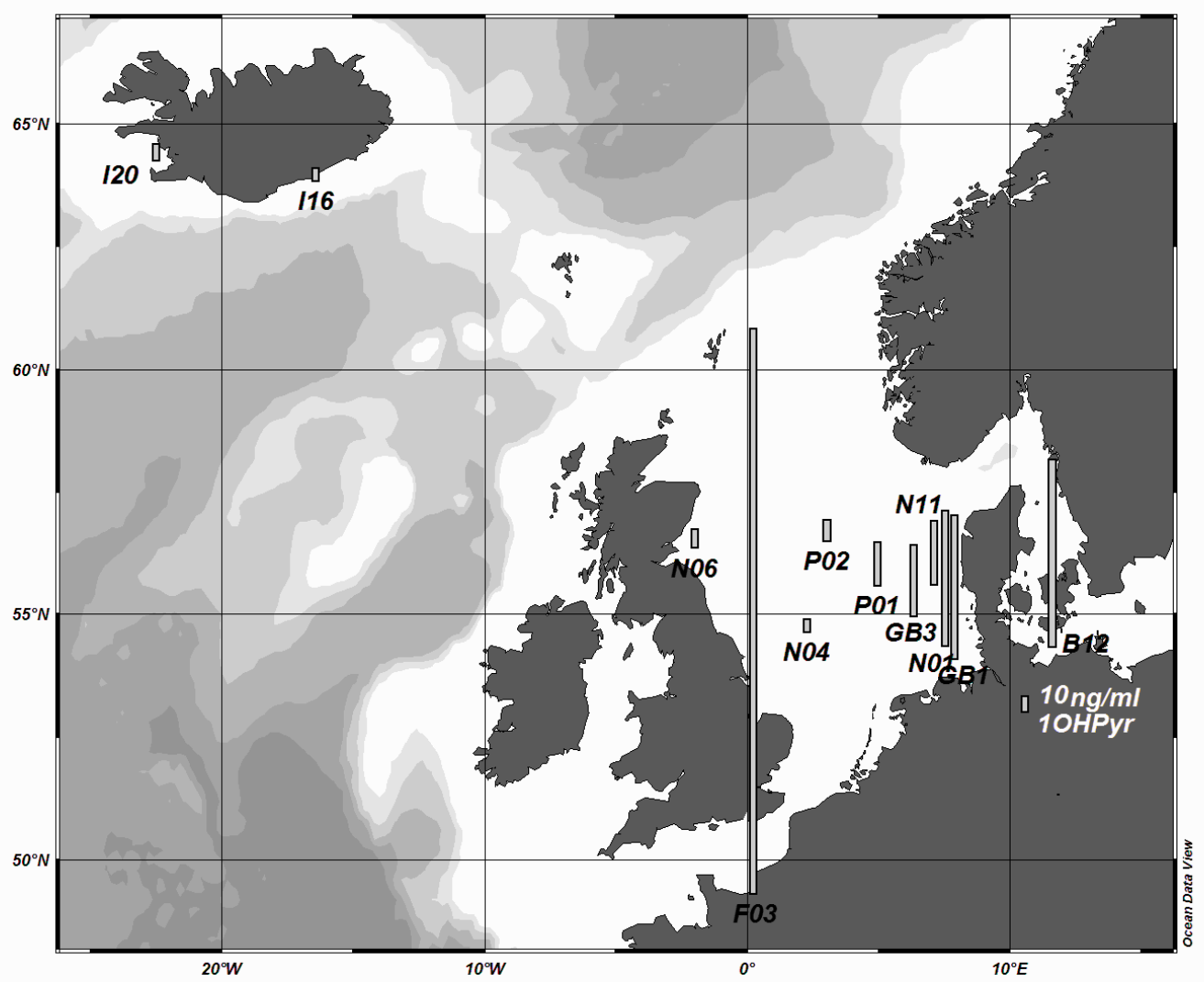

